\title{
O jednom dobrém člověku (pohádka)
}

\section{On a Good Man (A Fairytale)}

\author{
Ivana Holzbachová
}

Milé děti,

budu vám nyní vyprávět o jednom člověku, který se zapsal a stále zapisuje do mého života. A protože ten člověk nebyl sám, budu vyprávět i o jiných lidech, kteří s ním (a se mnou) sdíleli nebo ještě sdílejí část svých životů.

Jako pomůcka mi pro začátek mého vyprávění poslouží index. Že nevíte, co to byl index? To byl takový malý sešitek v tvrdých deskách, do kterého si student po celých pět let svého studia zapisoval všechny předměty, které studoval, a vyučující mu na konci semestru do něj napsal známku - a podepsal se. Takže na rozdíl od vás mám docela slušnou sbírku autogramů. To víte, na počátku 60. let byla elektronika zastoupena především pevnou telefonní linkou a v některých kancelářích i elektrickým psacím strojem.

Otevírám index a hledám. Pan (tehdy se říkalo soudruh) doktor Jiří Gabriel mne v ní doprovázel první tři roky studia. Učil mne logiku, filozofické problémy náboženství a dějiny české filozofie. Ale kromě toho učil mne i mé spolužáky něčemu jinému a možná dưležitějšímu: slušnosti, pravdivosti, zápalu pro věc a píli. Tedy těm věcem, bez nichž a bez jejich kombinace by se žádný člověk neměl obejít. Ale nemyslete si, pan doktor Gabriel nebyl žádný suchar. S jeho smyslem pro kamarádství a humor se setkávali ti, kdo jezdili na katedrové exkurze, i ti, kdo s ním a dalšími studenty a učiteli naší fakulty postávali u piva U Čápa nebo seděli v Akademické kavárně. Často se tyto sedánky měnily v opravdové semináře.

Měla jsem to štěstí, že jsem studovala v letech tzv. uvolnění a že mne učili relativně mladí lidé, kteří však už za sebou měli léta šílenství padesátých let a kteří se naučili, že existuje rozdíl mezi ideologií a vědou a že svět je daleko složitější, než se zdálo ještě pár let před tím. Že není černobílý a že je třeba prozkoumávat jeho nuance. Byla to doba, na kterou dnešní zapálení 
kritikové „komunismu“ často a rádi zapomínají a jejíž aktéři už pomalu odcházejí na cestu, ze které není návratu. Jiří Gabriel je jedním z nich, z těch, kteří věřili (možná naivně) v možnost vybudovat lepší společnost. (Podobně - a podobně naivně - v to věřilo na přelomu osmdesátých a devadesátých let mnoho těch lidí, kteří odmítli zvrhlou variantu té předchozí představy o lepší společnosti. Jak totiž píše K. R. Popper, ve společnosti jsou důležité instituce, které je však nutno obsadit lidmi. A jak píše další klasik, „moc korumpuje“.)

Idyla skončila v srpnu 1968 a zvláště na počátku sedmdesátých let měla katedra, na které jsem studovala a po absolutoriu zůstala, namále, stejně jako celá fakulta. (Dodnes věřím, že jen zásluhou tehdejšího děkana, rusisty Bořivoje Nováka, to nedopadlo ještě hưř.) Filozofie se přestala učit a několik let trvalo, než si i komunisté u moci uvědomili, že občanská nauka patří na pedagogickou fakultu a filozofie na filozofickou.

Po „uklidnění“ největší bouře většina členů katedry na ní zůstala, i když ti, kdo ztratili členství v KSC̆ (do roku 1969 bylo pro naše učitele povinné) byli různými způsoby omezováni. To se týkalo i Jiř́iho Gabriela. Přesto jsme žili v relativním klidu pod ochranou těch, kterým bylo povoleno ve straně zůstat. Do určité míry nám to umožňovalo věnovat se vědecké práci, i když ne všichni směli na počátku publikovat. Ale i práce „do šuplíku“ se dala později - v osmdesátých letech - zúročit. Proto jsem mohla obdivovat Jiř́ho práci organizátorskou. Podílel se na několika mezinárodních konferencích, které proběhly v Brně a byly věnovány mj. i dějinám české filozofie. Postupně se vytvářela "silná trojka“ tvořená Jiřím Gabrielem a o necelou generaci mladšími Helenou Pavlincovou a Janem Zouharem, kteří měli tehdy a ještě více po roce 1989 na svědomí množství publikací, jež se týkaly právě dějin české filozofie. Snad nejvýznamnější je Slovnik českých filozofi̊ který vyšel v r. 1998 a doted’ žije na internetu a je neustále doplňován.

Během „normalizace“ nepřestal Jiří Gabriel působit jako výkonný redaktor filozofické řady Sborniku praci FFBU (nyní Studia philosophica, jejichž výtisk právě držíte v ruce, pokud to ovšem nečtete na webové stránce časopisu). V roce 1988 získal (konečně) titul CSc. a hned po sametové revoluci v r. 1990 byl jmenován docentem dějin filozofie. Toto jmenování jsme dostali oba, on i já, jako jmenování rehabilitační. Nezapomenu na naše společné rozhořčení, protože jsme byli oba přesvědčeni, že si svou prací zasloužíme řádné habilitační řízení.

A další paradox: Na UJEP (název univerzity v době totality) vycházel od roku 1968 časopis Universitas, který se věnoval vědeckému i politickému dění na univerzitě. Jeho kvalita byla kolísavá, horší bylo, že se nám všem 
vnucovalo jeho odebírání. Nakonec všichni odpírači skončili na koberečku u děkana. Povolili všichni, kromě nás dvou: Jiř́ího a mne. V roce 1990, když se reformovala redakce časopisu, bylo jeho vedení nabídnuto právě nám. Kolega se projevil jako darebák: hodil šéfredaktorskou odpovědnost na mne, a přivodil mi tak nemálo bezesných nocí.

Mezi staršími i mladšími členy katedry se docent Gabriel jevil spíš jako člověk nenápadný. Ale tomuto zdání odporuje hora práce, kterou vykonal nebo inspiroval, a množství studentů, které nadchl pro výzkumy, jež realizoval. I poté, co odešel do důchodu, spolupracoval na edici Masarykových spisů, často se objevoval na katedře a jeho nápady dokázaly vyvolat živé a vtipné diskuse. I když ted’ na fakultu ze zdravotních důvodů nedochází, podnětné nápady mu nechybí.

Jiří patřil a patří k dobrým duchům katedry dlouhé desítky let. Letos slaví devadesáté narozeniny a všichni doufáme, že pohádka jeho života bude pokračovat ještě dlouho.

\section{doc. PhDr. Ivana Holzbachová, CSc.}

Katedra filozofie, Filozofická fakulta, Masarykova univerzita

Arna Nováka 1, 60200 Brno, Česká republika

holzbach@phil.muni.cz 
